\title{
Transverse microhardness of artificial teeth
}

\author{
- Regina Tamaki Department of Prosthodontics, School of Dentistry, University of São Paulo, São Paulo, SP, \\ Brazil • Carolina Mayumi legami Department of Prosthodontics, School of Dentistry, University of São Paulo, São Paulo, \\ SP, Brazil • Priscila Nakasone Uehara Department of Prosthodontics, School of Dentistry, University of São Paulo, São \\ Paulo, SP, Brazil - Ricardo Jun Furuyama Department of Prosthodontics, School of Dentistry, University of São Paulo, \\ São Paulo, SP, Brazil • Rafael Yague Ballester Department of Biomaterials and Oral Biochemistry, School of Dentistry, \\ University of São Paulo, São Paulo, SP, Brazil
}

ABSTRACT | Objective: Hardness is an indicator of several mechanical properties of artificial teeth, also related to wear resistance. The purpose of this article is to map the microhardness of artificial teeth as a function of depth and commercial brand. Methods: Knoop microhardness of sectioned artificial second molars was measured every $200 \mu \mathrm{m}$ starting at a depth of $100 \mu \mathrm{m}$ up until $4700 \mu \mathrm{m}$ of the following brands: Premium (Pr), Orthosit (Or), SR Postaris DCL (Po), Biotone (Bi), Artiplus IPN (Ar), VITA MFT (Vi), Natusdent (Na), Trilux (Tr), and Biolux (Bx). Results were analyzed with ANOVA for repeated measures and Tukey test (5\%). Results: SR Orthosit PE commercial brand presented higher hardness values (until the depth of $3.1 \mathrm{~mm}$ was $30 \mathrm{~N} / \mathrm{mm}^{2}$ ), significantly higher than the other brands analyzed. Conclusion: Knoop hardness did not present differences between layers for eight of the nine brands studied. Different hardness values were found between superficial and cervical areas for the brand SR Orthosit PE.

DESCRIPTORS | Artificial Tooth; Hardness; Acrylic Resins.

RESUMO | Microdureza de dentes artificiais em suas diferentes camadas - Objetivo: A dureza é tida como indicador de várias propriedades mecânicas de dentes artificiais, e relacionada a resistência ao desgaste. O objetivo foi mapear a microdureza de dentes artificiais de 9 marcas em função da profundidade. Métodos: foi medida a microdureza Knoop de segundos molares cortados num plano sagital em intervalos de $200 \mu \mathrm{m}$ a partir da profundidade de $100 \mu \mathrm{m}$ até $4700 \mu \mathrm{m}$, das marcas: Premium (Pr), Orthosit (Or), SR Postaris DCL (Po), Biotone (Bi), Artiplus IPN (Ar), VITA MFT (Vi), Natusdent (Na), Trilux (Tr) and Biolux (Bx). A ANOVA de medidas repetidas e o teste de Tukey (5\%) analisaram os resultados. Resultados: A marca SR Orthosit PE apresentou a maior dureza (até a profundidade de 3,1 mm foi da ordem de $30 \mathrm{~N} / \mathrm{mm}^{2}$ ), significativamente maior que todas as outras medidas realizadas (da ordem de $20 \mathrm{~N} / \mathrm{mm}^{2}$ ). Conclusão: A dureza Knoop não evidenciou diferenças entre camadas para oito das nove marcas estudadas. Foi constatada diferente dureza entre a superfície e a região cervical para a marca SR Orthosit PE.

DESCRITORES | Dente Artificial; Dureza; Resinas Acrílicas.

\author{
CORRESPONDING AUTHOR | • Regina Tamaki Department of Prosthodontics, School of Dentistry, University of \\ São Paulo • Av. Professor Lineu Prestes, 2227, Cidade Universitária São Paulo, SP, \\ Brazil • 05508-000 Email: retamaki@usp.br \\ - Received Jul 18,2015 • Accepted Sep 02, 2015 \\ - Dol http://dx.doi.org/10.11606/issn.2357-8041.clrd.2015.122750
}




\section{INTRODUCTION}

Artificial teeth selection represents an important contributing factor for the rehabilitation success of edentulous subjects. Wear resistance of artificial teeth during function and the outcome of the treatment are related, as masticatory efficiency, vertical dimension maintenance, and denture longevity depend on wear resistance. However, occlusal wear of acrylic resin teeth is a common complication. ${ }^{1}$ One study shows that the wear of most acrylic tooth tested by sliding against enamel was significantly greater than that of porcelain material against enamel, ${ }^{2}$ suggesting that the best combination for wear is porcelain-enamel, although this combination is able to produce micro cracks in enamel (50\% of the samples).

To enhance the wear resistance, manufacturers have developed new materials, such as micro-filled composite and/or cross-linked and/ or interpenetrated polymer network and/or different monomers..$^{3-8}$ The latter being the case of Trubyte Bioform IPN (Dentsply International/ Pennsylvania, USA). Literature states that this product contains interpenetrated polymer networks (IPN), which are materials made of two polymers, each one in a different network shape, one network being inside the other. ${ }^{6-9}$ Another manufacturer (Sustained Life Material - Dentsply, PA) despite not self-qualifying as IPN, declares that there would be an improvement in this product (Trublend SLM) caused by the incorporation of cross-links in the polymer networks with polyethylene particles of high molecular weight, which would also enhance the lubricant effect. ${ }^{8,10}$ Composite resin teeth with silica particles were found in SR-Ortosit PE (Ivoclar, Schaan, Liechtenstein), detected by the analysis with EDX. ${ }^{5}$

Wear resistance improvement is usually accompanied by the decrease of artificial teeth-denture base adhesion, because this adhesion is related to the ability of the monomer to induce the swelling of the resin polymer, which decreases as the polymer cross-linked rate increases. Likewise, a high percentage of filler particles increases wear resistance, but the polymer area available for adhesion decreases. ${ }^{11}$

Manufacturers have overcome this properties contraposition by making artificial teeth in layers of different compositions. The layer corresponding to the enamel layer is expected to be resistant to fissures, solvents, and wear, while the base layer should present a lower degree of cross-links, allowing a better adhesion to the acrylic resin. ${ }^{12}$ Therefore, the different layers of the artificial teeth can present specific properties of hardness and monomer diffusion. ${ }^{5}$ Conventional acrylic resin teeth can also be made in layers, aiming at aesthetics improvement.

The grinding of the external layer corresponding to the enamel in artificial teeth might be caused by chewing or by occlusal adjustments performed by the dentist. ${ }^{6}$ One of the reasons that might determine these adjustments is the polymerization process and the resin base contraction, which can displace the artificial teeth and change the occlusal contacts. ${ }^{13}$ In addition, after a period of adaptation, the denture is accommodated in the mucosa and the tooth arrangement need to be adjusted..$^{14}$ In addition to the grinding of the external layer, the material removal of the cervical region is also performed when there is not enough space for tooth placement. In these cases, the most favorable of the tooth area might be reduced for the denture base adhesion, which is the region that presents a smaller degree of cross-linked polymer. In both situations, wear affects the performance of teeth manufactured in layers with specific properties.

No reports of hardness values through the various layers of artificial teeth were found in the literature. Hardness is considered a material property related to wear resistance and it is usually used as an indicator of several mechanical properties of synthetic restorative materials and artificial teeth. ${ }^{15-17}$

The aim of this study was to map the microhardness of nine artificial teeth brands according to depth. The null hypotheses were that all commercial brands of analyzed teeth present 
similar hardness and that all depths present similar hardness.

\section{MATERIALS AND METHODS}

Microhardness was measured on upper second molars of each commercial brand $(n=3)$ : Premium (Pr) (Heraeus Kulzer GmbH/Hanau, Germany), Orthosit (Or) (Ivoclar-Vivadent AG/ Schaam, Liechtenstein), SR Postaris DCL (Po) (Ivoclar-Vivadent AG/Schaam, Liechtenstein), Biotone (Bi) (Dentsply/Petrópolis, Brasil), Artiplus
IPN (Ar) (Dentsply International/Pennsylvania, USA), VITA MFT (Vi) (Vita Zahnfabrik/Bad Säckingen, Germany), Natusdent (Na) (Dentbras Industria, Comercio, Importacao e Exportacao de Produtos Odontologicos Ltda/Pirassununga, Brazil), Trilux (Tr) (VIPI Indústria Comércio Exportação Importação de Produtos Odontológicos Ltda/Pirassununga, Brazil), and Biolux (Bx) (VIPI Indústria Comércio Exportação Importação de Produtos Odontológicos Ltda/Pirassununga, Brazil) (Table 1).

Table 1 | Brand of denture teeth used (information supplied by the manufacturer)

\begin{tabular}{|c|c|c|c|}
\hline Denture teeth & Code & Characteristics & Manufacturer \\
\hline Artiplus IPN & $\operatorname{Ar}$ & PMMA; BADMA18; high quality INPEN $®$ material & Dentsply Ind e Com Ltda., Petrópolis, RJ, Brazil \\
\hline Biolux & $\mathrm{Bx}$ & PMMA; EDMA; double cross-linked & Vipi Ind. e Com Ltda., Pirassununga, SP, Brazil \\
\hline Biotone IPN & $\mathrm{Bi}$ & PMMA; high-performance density cross-linked resin & Dentsply Ind e Com Ltda., Petrópolis, RJ, Brazil \\
\hline Natusdent & $\mathrm{Na}$ & PMMA; EDMA & $\begin{array}{l}\text { Dentbras Industria, Com. Imp e Exp. de Produtos } \\
\text { Odontológicos Ltda., Pirassununga, SP, Brazil }\end{array}$ \\
\hline Premium & $\operatorname{Pr}$ & $\begin{array}{l}\text { PMMA; MPM (multiple polymeric matrix); microfiller } \\
\text { combined with a viscoelastic nano filler (Nano Pearls }{ }^{\circledR} \text { ) }\end{array}$ & Heraeus Kulzer, GmbH/Hanau, Germany \\
\hline SR Orthosit PE & Or & Isosit; UDMA6; highly cross-linked & Ivoclar Vivadent, Inc., Amherst, New York \\
\hline SR Postaris DCL & Po & High-performance double cross-linked & Ivoclar Vivadent, Inc., Amherst, New York \\
\hline Trilux & $\operatorname{Tr}$ & $\begin{array}{l}\text { PMMA; EDMA; OMC (Organically Modified Ceramic); } \\
\text { double cross-linked }\end{array}$ & Vipi Ind. e Com Ltda., Pirassununga, SP, Brazil \\
\hline VITA MFT & Vi & PMMA; densely cross-linked & Vita Zahnfabrik, Bad Säckingen, Germany \\
\hline
\end{tabular}

Note: PMMA, polymethyl methacrylate; BADMA, butylene glycol dimethacrylate; EDMA, dimethacrylate of polymerized ethylene glycol.

Artificial teeth were grinded in the frontal plane until the tip of the mesial cusps was reached. Fragments were imbedded in a $1 / 2$ inch polyvinyl chloride (PVC) tube (Tigre SA, Brazil) with chemically activated acrylic resin (Jet Classico/São Paulo, Brazil). After complete cure, samples were polished with the following sandpaper (Norton, Brazil) sequence: 320, 400, 500, 600, 800, 1200, and 2000. At each grit change, samples were washed during thirty seconds in running water.

Knoop microhardness was measured with a HMV-2000 micro durometer (Shimadzu, Japan) attached to a computer and a Cams-Win software (New Age Industries, USA). A 25 gf load was applied for $15 \mathrm{~s}$, and the longer diagonal was measured in
40X. Twenty-two sequential indentations were applied in each specimen: the first indentation started in a distance of $100 \mu \mathrm{m}$ from the occlusal surface of the tip of the palatal cusp and the next 21 were applied sequentially in increments of $200 \mu \mathrm{m}$ towards the center of the cervical line of the tooth-cutting plane. Despite Vickers hardness being used for artificial teeth analysis, ${ }^{19,20}$ the selection of Knoop hardness appeared to be more appropriate, since the longer diagonal is less susceptible to dimensional alterations and, as a consequence, Knoop hardness value does not depend on material ductility. ${ }^{3}$

Data related to depths of 100, 300, 1100, 2100, 3100 , and $4100 \mu \mathrm{m}$ were analyzed on Statistica 8.o software (StatSoft. Inc., USA) with repeated 
measures ANOVA analysis. The comparison between means was done with Tukey test $(\alpha \leq 0.05)$.

\section{RESULTS}

Variance analysis presented significance for all variance factors: brand $(\mathrm{p}<0.001)$, depth $(\mathrm{p}<0.01)$, and the interaction factors $(\mathrm{p}<0.001)$.

The brand Or presented hardness means significantly higher than the other brands, with depths from 100 to $3100 \mu \mathrm{m}$. However, at the $4100 \mu \mathrm{m}$,
Or hardness does not differ significantly from the other brands. Among the other brands, some significant differences were observed according to depth. The lower numerical value of hardness mean was obtained for the brand $\operatorname{Tr}(16 \pm 0.6)$ in the 100$\mu \mathrm{m}$ depth, yet this value does not differ significantly from other 37 means. In general, the hardness of all brands does not significantly differ from each other, except for the brand Or until the depth of $3100 \mu \mathrm{m}$, as shown on Graph 1 .

Graph 1 | Graphical presentation of Knoop hardness means of the interaction between commercial brand vs. depth

Current effect: $F(40,90)=3,0165, p=, 00001$

Effective hypothesis decomposition

Vertical bars denote 0,95 confidence intervals

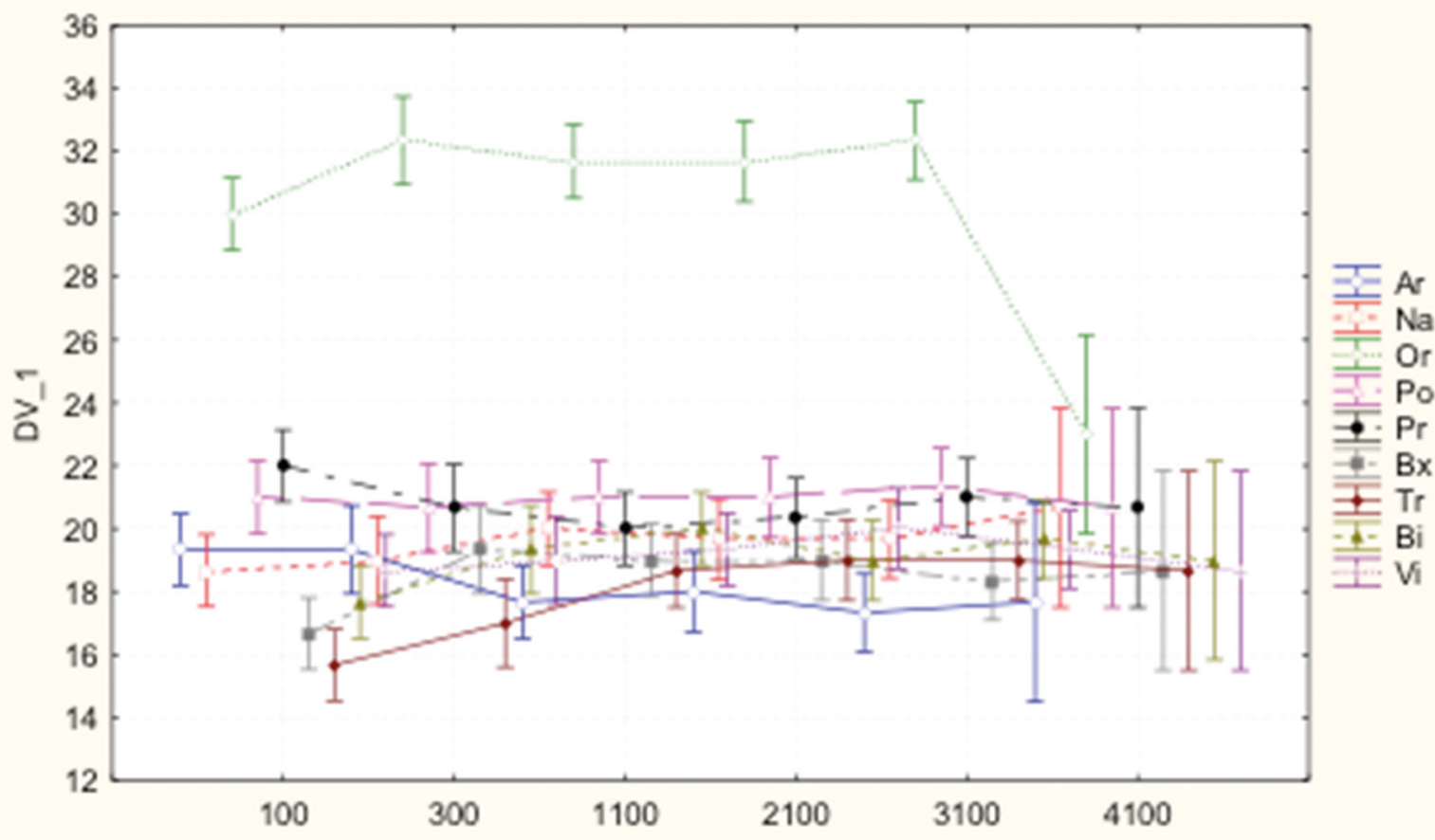

\section{DISCUSSION}

The analysis results allowed the rejection of the null hypotheses, since not all teeth brands presented similar hardness (Or is harder than all of the other brands, except in its deeper layer) and not all depths presented similar hardness (as Or presents significant hardness differences depending on depth). The difference between hardness values denotes a difference in resin quality, which might or not influence the teeth's clinical performance. According to some authors ${ }^{21-23}$, it would be expected from teeth or layers with similar hardness similar wear behavior. As a principle, an increased hardness might be the result of a higher degree of polymer cross-links and/or inorganic filler particles, which could be related to a worse adhesion between the denture resin base and the teeth. 
Some of the indentations at $100 \mu \mathrm{m}$ presented a tendency of lower hardness than the ones further away from the occlusal surface. This tendency, which did not become significant for any of the brands, could be a result of a small superficial alteration caused by the contact of the acrylic resin monomer used for embedding the teeth for hardness testing. Another plausible reason could be the proximity of the specimen margin, which is known to decrease hardness values because of low mechanical resistance of the thin layer between the indenter and the margin of the specimen. In any case, as the hardness variation was not statistically significant, it could be due to random variables and it should not have a major impact on the quality of the superficial layer.

The manufacturer informs that the Or tooth presents ISOSIT in its composition. It is difficult to know the current and exact composition of this restorative material, which is described ${ }^{24}$ as made of "organic filler and liquid matrix based on a modified Bowen resin," and has physical properties similar to the composites. Hardness values obtained in this study for the layers until $3.1 \mathrm{~mm}$ are comparable with the ones found in other studies that investigated hardness in composite resins. ${ }^{25,26}$ On the other hand, hardness in the layer distanced 4.1 $\mathrm{mm}$ from the surface was not significantly different from the hardness of the other brands, which might indicate that this area presents different composition from the other layers in the same tooth. Therefore, we can assume that the portion available for adhesion to the denture base is made of acrylic resin, which would promote a better adhesion. In a study ${ }^{5}$, the tooth SR Orthosit PE (coded as Or in this study) presented significant difference between the Vickers hardness values for the enamel and intermediate layers, and for the base layer. These results agree with the ones in this study.

The cross-link polymers are used to improve the properties of materials based on acrylic resin. The different types of monomers and proportions of cross-link agents might also influence the artificial teeth hardness. ${ }^{3,27}$ Among the nine brands evaluated in this research, only one manufacturer did not inform the presence of cross-link in the polymer (Na). Besides specific polymers to form cross-links, some manufacturers use other methods or components to enhance the performance of their teeth. The brand Ar uses IPN technology, which is defined as a combination of two or more polymers in network form that are synthetized in juxtaposition. ${ }^{28}$ They do not interpenetrate through the chemical reactions in a molecular scale, but are made of finely divided phases of 5-10 $\mathrm{nm} .{ }^{9}$ However, according to the manufacturer, $\operatorname{Pr}$ teeth are made with INCOMP technology, which includes MPM (multi polymeric matrix), which presents high cross-links.

Because of the hardness distribution found in this study (admitting that hardness is expressing the level of polymer crosslinking), even for the Or teeth, the smallest occlusal adjustment grinding might be safely executed, i.e, without damaging the clinical performance, because there will remain a thick layer of the harder material. However, if it is necessary to substantially reduce tooth height due to the lack of interocclusal space, grinding the cervical area of teeth from the Or brand would be contraindicated, because that could affect the adhesion of the tooth to the acrylic resin base. In this study, microhardness measurements were made until $4700 \mu \mathrm{m}$ of molars, which indicates that there would be approximately $0.5 \mathrm{~mm}$ of acrylic resin, a fact that, we assume, is maintained for the other teeth groups. For the studied brands, however, it would not be predictable to find issues of adherence to the denture base when a thicker grinding of the cervical area is needed because, as they do not present different hardness among the layers, it is not expected from the adhesive resistance to be different among them.

According to the available information (Table 1), the analyzed teeth, mainly manufactured with acrylic resin (Or teeth were not considered in this case, for it is mostly made of Isosit, which is a composite), present different chemical compositions, what could influence hardness values. However, in another study, ${ }^{5}$ a significant difference between the external layer solubility (correspondent to enamel) and the base layer was observed, which would show 
the differences of cross-link between them. The same authors also found a positive linear correlation between hardness and the inorganic content. Nevertheless, when Vickers hardness levels of conventional acrylic resin and high cross-linked resins were compared, the difference was not statistically significant. This would be a sign indicating that the hardness test would differentiate materials with and without fillers, but would not distinguish well cross-linked and non cross-linked resins. It seems interesting to intensify the studies on the correlation between adhesion resistance to the base resin, the solubility of the hardened resin in the monomer and hardness, since the hardness test is easy to apply, however its result might not be useful to clarify certain desirable behaviors of artificial teeth.

In another study, ${ }^{6}$ the correlation between wear resistance, hardness and elastic modulus in the layer that corresponds to the dentin was analyzed. Tests were performed in seven artificial teeth brands, among them SR Orthosit PE. Wear resistance was tested in a pin/disc design using nanoindentation. A positive significant correlation between hardness and elastic modulus was observed. Yet no correlation between wear (weight and volume loss) and mechanical properties (hardness and elastic modulus) was found. ACE Teeth and SR Orthosit PE teeth presented the higher hardness and elastic modulus values compared with the other teeth analyzed.

\section{CONCLUSION}

Only SR Orthosit PE commercial brand presented significantly higher hardness from the superficial layer to the depth of $3.1 \mathrm{~mm}$, than in the cervical area. However, no other brands analyzed showed significant hardness differences among depths or among brands.

\section{REFERENCES}

1. Gothberg C, Bergendal T, Magnusson T. Complications after treatment with implant-supported fixed prostheses: a retrospective study. Int J Prosthodont. 2003 Mar-Apr;16(2):201-7.

2. Stawarczyk B, Özcan M, Trottmann A, Schmutz F, Roos M, Hämmerle C. Two-body wear rate of CAD/CAM resin blo- cks and their enamel antagonists. J Prosthet Dent. 2013 May;109(5):325-32. doi: 10.1016/Soo22-3913(13)60309-1.

3. Rawls HR. Dental polimers. In: Anusavice KJ. Phillips' science of dental materials. Philadelphia: Saunders; 2003 p. $143-66$.

4. Aoyagi Y, Takahashi H, Iwasaki N, Honda E, Kurabayashi T. Radiopacity of experimental composite resins containing radiopaque materials. Dent Mater J. 2005 Sep;24(3):315-20.

5. Loyaga-Rendon PG, Takahashi H, Hayakawa I, Iwasaki N. Compositional characteristics and hardness of acrylic and composite resin artificial teeth. J Prosthet Dent. 2007 Aug;98(2):141-9. http://dx.doi.org/10.1016/Soo22-3913(07)$60047-\mathrm{X}$

6. Suwannaroop P, Chaijareenont P, Koottathape N, Takahashi $\mathrm{H}$, Arksornnukit M. In vitro wear resistance, hardness and elastic modulus of artificial denture teeth. Dent Mater J. 2011;30(4):461-8. http://doi.org/10.4012/dmj.2010-200.

7. Toyooka H, Taira M, Wakasa K, Yamaki M, Fujita M, Wada T. Radiopacity of 12 visible-light-cured dental composite resins. J Oral Rehabil. 1993 Nov;20(6):615-22. doi: 10.1111/j.13652842.1993.tbo1648.x.

8. Vasconcelos LR, Consani RL, Mesquita MF, Sinhoreti MA. Effect of chemical and microwave disinfection on the surface microhardness of acrylic resin denture teeth. J Prosthodont. 2013 Jun;22(4):298-303. doi: 10.1111/jopr.12009.

9. Vallittu PK. Interpenetrating Polymer Networks (IPNs) in Dental Polymers and Composites. J Adhes Sci Techn 2009;23:96172. http://dx.doi.org/10.1163/156856109X432785.

10. Lindquist TJ, Ogle RE, Davis EL. Twelve-month results of a clinical wear study of three artificial tooth materials. $J$ Prosthet Dent. 1995 Aug;74(2):156-61. doi: 10

11. Vallittu PK, Ruyter IE, Nat R. The swelling phenomenon of acrylic resin polymer teeth at the interface with denture base polymers. J Prosthet Dent. 1997 Aug;78(2):194-9. http:// dx.doi.org/10.1016/Soo22-3913(97)70125-2.

12. Finer Y, Diwan R. The materials used. In: Zarb GA, Bolender CL, Eckert SE, Jacob RF, Fentorr AH, Merickske-Stern RM. Prosthodontic treatment for edentulous patients: complete denture and Implant-supported prosthesis. St. Louis: Mosby; 2003. p. 195-8.

13. Elahi JM, Abdullah MA. Effect of different polymerization techniques on dimensional stability of record bases. J Prosthet Dent. 1994 Feb;71(2):150-3. doi: 
14. Palla S. Occlusal considerations in complete dentures. In: McNeill C. Science and practice of occlusion. Chicago: Quintessence; 1997. p. 457-67.

15. Mandikos MN, McGivney GP, Davis E, Bush PJ, Carter JM. A comparison of the wear resistance and hardness of indirect composite resins. J Prosthet Dent. 2001 Apr;85(4):386-95. http://dx.doi.org/10.1067/ mpr.2001.114267.

16. Suzuki S. In vitro wear of nano-composite denture teeth. J Prosthodont. 2004 Dec;13(4):238-43. doi: 10.1111/j. 1532-849X.2004.04043.x.

17. Zeng J, Sato Y, Ohkubo C, Hosoi T. In vitro wear resistance of three types of composite resin denture teeth. J Prosthet Dent. 2005 Nov;94(5):453-7. http://dx.doi.org/10.1016/j. prosdent.2005.08.010.

18. Hipólito AC, Barão VA, Faverani LP, Ferreira MB, Assunção WG. Color degradation of acrylic resin denture teeth as a function of liquid diet: ultraviolet-visible reflection analysis. J Biomed Opt. 2013 Oct;18(10):105005. doi: 10.1117/1. JBO.18.10.105005.

19. Campanha NH, Pavarina AC, Vergani CE, Machado AL. Effect of microwave sterilization and water storage on the Vickers hardness of acrylic resin denture teeth. J Prosthet Dent. 2005 May;93(5):483-7. http://dx.doi.org/10.1016/j. prosdent.2005.02.016.

20. Pavarina AC, Vergani CE, Machado AL, Giampaolo ET, Teraoka MT. The effect of disinfectant solutions on the hardness of acrylic resin denture teeth. J Oral Rehabil. 2003 Jul;30(7):749-52. doi: 10.1046/j.1365-2842.2003.01145.x.
21. Chittaranjan B, Taruna M, Sudheer N, Patil NS. Evaluation of shear bond strength of three different types of artificial teeth to heat cure denture base resin: an in vitro study. Indian J Dent Res. 2013 May-Jun;24(3):321-5. doi: 10.4103/o9709290.117994.

22. Korkmaz T, Dogan A, Dogan OM, Demir H. The bond strength of a highly cross-linked denture tooth to denture base polymers: a comparative study. J Adhes Dent. 2011 Feb;13(1):8592. doi: 10.3290/j.jad.a18241.

23. Takahashi Y, Chai J, Takahashi T, Habu T. Bond strength of denture teeth to denture base resins. Int J Prosthodont. 2000 Jan-Feb;13(1):59-65.

24. Michl RJ. Isosit - a new dental material. Quintessence Int. 1978 Mar;9(3):29 [citado 01 dez. 2015]. Disponível em: http:// bit.ly/2mTmzZR

25. Chang M, Dennison J, Yaman P. Physical property evaluation of four composite materials. Oper Dent. 2013 Sep-Oct;38(5):E144-53. doi: 10.2341/12-203-L.

26. Price RB, Fahey J, Felix CM. Knoop microhardness mapping used to compare the efficacy of LED, QTH and PAC curing lights. Oper Dent. 2010 Jan-Feb;35(1):58-68. doi: 10.2341/o9-055-L.

27. Arima T, Murata H, Hamada T. The effects of cross-linking agents on the water sorption and solubility characteristics of denture base resin. J Oral Rehabil. 1996 Jul;23(7):476-80. doi: 10.1111/j.1365-2842.1996.tboo882.x.

28. Sperling LH. Interpenetrating polymer networks: an overview. In: Kempler D, Sperling LH, Utrack LA. Interpenetrating polymer networks. Washington: American Chemical Society; 1994. p. 3-11. 